\title{
Governance reform pressures and processes in the NHS in Scotland
}

\author{
Alice BELCHER ${ }^{1}$
}

University of Dundee

\begin{abstract}
Introduction
$I_{r}^{n}$ $\mathrm{n}$ the private sector the collapse of Enron has been seen as putting corporate governance processes under significant pressure, so much so that "post-Enron" is a well-recognised and frequently used phrase. This article moves outside the private sector, but remains focused on organisations with large budgets and the potential for large corporate governance problems. It examines corporate governance developments, mostly postEnron, in the NHS in Scotland. NHS boards in Scotland are public bodies operating in a country where health has been a devolved matter since 1998. This article aims to reveal the corporate governance pressures that affect NHS board governance in Scotland, including those that can be traced back to Enron. There are various sources for the pressures that might be expected to impact on the corporate governance of the NHS in Scotland including: UK corporate governance pronouncements; UK public sector pronouncements; more generally the world of corporate governance pre- and post-Enron; pressures particular to devolved Scotland; ${ }^{2}$ and changes to UK level regulation of the healthcare professions. The processes that determine the shape of corporate governance in the NHS are, generally, much more "top down" and directed than the private sector equivalent in the UK. Pre-devolution, ministerial and parliamentary direction came from London (Westminster). After devolution, statutes of the Scottish Parliament and HDLs ${ }^{3}$ issued by the relevant minister became the most immediate source of NHS governance rules.

Following this introduction the article has a short chronology giving an outline of relevant events pre- and post-Enron. It then explores the influence of private sector corporate governance developments post-Enron. The influence of the approach to internal control taken by the Turnbull Guidance is considered separately as this spans the pre- and post-Enron periods but is an important corporate governance development in the private sector that spills over to the NHS. Finally, the article explains and assesses some governance

1 The author acknowledges the assistance of AHRC Network award AH/E510620/1: see www.dundee.ac.uk/artsoc/rig/ and the opportunity to present and discuss an earlier version at the ESRCfunded colloquium "The Globalization of Corporate Governance? Reform pressures and processes in an era of financial crises", 17-18 September 2008, Queen's University Belfast under the aegis of the "Regulatory Regime Change in Financial Markets: the Case of Sarbanes-Oxley" project.

2 Currently under the SNP.

3 Health Department Letters.
\end{abstract}


developments that are happening in the NHS in Scotland that are being driven by the "public involvement" agenda of the current Scottish Government, in particular, the introduction of board members directly elected to health boards.

\section{Chronology}

This chronology picks out a few key developments concerning the NHS, the public sector and Scotland and positions them against corporate governance landmarks both before and after Enron. The NHS has gone through many reforms over its sixty-year history. In 1990, the National Health Service and Community Care Act 1990 brought the concept of the "internal market" to the NHS and with it ideas about the operation of markets and financial performance that had previously been unknown. The corporate governance ideas of the Cadbury Code, published in 1992, were transferred to the NHS almost immediately with the introduction in 1994 of the first NHS Codes of Conduct and Accountability. ${ }^{4}$ Also around this time the Nolan Report, published in 1995, included seven Principles of Public Life which remain relevant benchmarks of behaviour. ${ }^{5}$

Under the Scotland Act 1998, some of Westminster's powers were devolved to a Scottish Parliament. One devolved area is health and, almost immediately, the NHS in Scotland was taken back into the public sector and put under direct ministerial control. The current system of governance for the NHS in Scotland was set out in the 2001 White Paper Rebuilding our National Health Service. This was followed by the Health Boards (Membership and Procedure) (Scotland) Regulations 2001 which constituted many of the NHS organisations in Scotland as either territorial health boards or special health boards. The special health boards cover the whole of Scotland, for example, the Scottish Ambulance Service. All these boards are public bodies reporting directly to the relevant minister. The move away from the market and back towards direct ministerial control came immediately before the Enron collapse; Enron entered “chapter 11" in December 2001.

In the post-Enron period governance of the NHS in Scotland could continue to draw inspiration from private sector developments; or from specifically public sector governance initiatives; or from both. In the private sector, the main developments that followed Enron are found in the Higgs and Smith Reports. The other major development that straddles the pre- and post-Enron periods is the implementation of the internal control provision of the Cadbury Code following the publication in 1999 of the Turnbull Guidance. In 2004, the NHS in Scotland was finally constituted as simply health boards and special health boards when the remaining NHS trusts were dissolved under the National Health Service Reform (Scotland) Act 2004. In the public sector more generally, 2004 also saw the publication of The Good Governance Standard for Public Services. ${ }^{6}$

\section{The influence of the private sector post-Enron}

The contents and impact of the Higgs Report are well known to UK corporate governance scholars. Commissioned by the Secretary of State, Patricia Hewitt, and the Chancellor, Gordon Brown, Higgs produced a consultation paper in June 2002, responses were accepted until September 2002, and the final report was issued in January 2003. Both the consultation paper and the final report were entitled Review of the Role and Effectiveness of Nonexecutive Directors. The report's influence on the public sector can be seen in the 2004 standard already mentioned. For public bodies in Scotland, it can also be seen in the training

4 A Belcher, "Codes of conduct and accountability for NHS Boards" (1995) (summer) Public Law 288-97.

5 Nolan Committee, First Report on Standards in Public Life (London: HMSO, 1995).

6 Independent Commission for Good Governance in Public Services, The Good Governance Standard for Public Services (London: OPM 2004). 
material issued to board members: On Board: A guide for board members of public bodies in Scotland was published in $2006 .^{7}$ The role of the board member focuses on four key areas: strategy, performance, risk and behaviour. ${ }^{8}$ It also states that the effective non-executive board member:

- upholds the highest ethical standards of integrity and probity (and complies with the public body's Code of Conduct for Board Members);

- supports executives in their leadership of the business while monitoring performance;

- questions intelligently, debates constructively, challenges rigorously and debates dispassionately;

- listens sensitively to the views of others, inside and outside the board;

- gains the trust and respect of other board members;

- and maintains a focus on strategy and performance and is not distracted by detail. ${ }^{?}$

The NHS in Scotland could only understand and implement this sort of guidance due to the earlier reforms required by the Health Boards (Membership and Procedure) (Scotland) Regulations 2001 which were themselves accompanied by guidance issued by the Scottish Executive Health Department in May 2001. 10 Under this guidance the board (of directors) of a health board (organisation) is said to be a "Board of Governance" and is "not a management Board" but "will have collective responsibility for the performance of the local NHS". Boards are held to account for their performance through the Local Delivery Plan; a set of targets agreed with, or sometimes dictated by, the Scottish Government Health Department. There is also an annual review process. This is probably the closest thing there is to an AGM. The public can be present and can ask questions if the board is notified in advance. It should be noted, however, that the chair of the audit committee is not required to be present at the annual review and often is not. This is one Smith Report requirement that has not been followed through by the NHS in Scotland.

The board of directors of an NHS territorial board currently comprises executive directors appointed by the minister, an employee board member, non-executive directors appointed through the public appointments system and, again, formally appointed by the minister, and members nominated from the local councils for the territory it covers. Boards of directors of special health boards do not have councillor members, but are otherwise the same. Both types broadly match the private sector form of a unitary board comprising executives and non-executives. However, board meetings ${ }^{11}$ are held in public and this sometimes means a press presence. Another way in which the NHS governance structure differs from the private sector is that the board is collectively responsible, but there is also a named "accountable officer", usually the chief executive, who is personally responsible.

7 Scottish Executive, On Board: A guide for board members of public bodies in Scotland (Edinburgh: Scottish Executive 2006).

8 These roles map onto the "strategy, performance, risk and people" roles of Good Practice Suggestions from the Higgs Report (London: FRC June 2006).

9 Scottish Executive, On Board, n. 7 above, para. 3.7.

10 "Rebuilding our National Health Service: guidance for NHS chairs and chief executives for implementing 'Our National Health': a plan for action, a plan for change” (Edinburgh: Scottish Executive Health Department May 2001). Under the current administration, the Scottish Executive Health Department has been renamed the Scottish Government and the Health Department (SGHD) and is now part of the Ministry of Health and Wellbeing.

11 But not board workshops or subcommittee meetings. 
The annual report for NHS Education for Scotland (NES) has statements by the board as a whole acknowledging their collective responsibility and a statement by the accountable officer acknowledging their personal responsibility. ${ }^{12}$ The accountable officer appears to be a public sector concept that has been retained despite its incompatibility with the unitary board governance structure imported from the private sector.

A second private sector response to Enron was the Smith Report giving "Audit committees Combined Code guidance". ${ }^{13}$ Again this followed on from government action in establishing the Co-ordinating Group on Auditing and Accounting Issues. Key Smith Report changes to the existing Corporate Governance Code were; that the audit committee is to comprise three independent non-executive directors and at least one is to have recent relevant financial experience; ${ }^{14}$ that the audit committee should have written terms of reference; ${ }^{15}$ that the audit committee should have a separate section in the annual report; ${ }^{16}$ and that the chair of the audit committee should be available to answer questions at the AGM. ${ }^{17}$ The requirements for recent relevant financial experience and written terms of reference have been taken up by the NHS. The availability of the audit committee chair has already been discussed, but in the NHS in Scotland there is no exact equivalent of the AGM. The recommendation for a separate section in the annual report for audit committee has also not been taken up in the NHS in Scotland, and health board annual reports vary considerably in their approaches to all types of corporate governance disclosure.

\section{The Turnbull Guidance and the NHS}

The Turnbull Guidance has been described as the last piece in the corporate governance jigsaw as it implements the "internal control" provision of the Cadbury Code of Best Practice. The guidance was first published in April 1999 with a revised version in June 2005. ${ }^{18}$ Thus, its development began pre-Enron and continued post-Enron. It is the Turnbull Guidance that is responsible for the risk management focus of internal control including the all-pervasive risk registers and risk matrices. Various problems with risk assessment, risk management and risk policy reporting have been addressed by Belcher ${ }^{19}$ and such problems may well have been the root cause of the recent spate of bank collapses. Nevertheless the technology of risk management has been transferred to the NHS. In particular clinical governance committees now form part of the overall governance structure of most NHS organisations including all NHS boards in Scotland that have clinical activities. ${ }^{20}$ Risks arising in clinical situations were seen as the major area needing risk management, however, not all risk is clinical risk even in the territorial health boards and there has, therefore, been a question of how and where other risk is captured and managed. In the Greater Glasgow and Clyde Health Board, clinical risk is the responsibility of the medical director, and non-clinical risk is the responsibility of the human resources

12 NES is a special health board. Health board annual reports vary considerably in their presentation and contents. Corporate governance disclosures are not standardised.

13 January 2003. Latest version issued by the Financial Reporting Council (FRC) as Guidance on Audit Committees (London: FRC October 2008).

14 Code Provision C.3.1 - two non-executives for small companies.

15 Code Provision C.3.2.

16 Code Provision C.3.3; a provision that overlaps with FSA Listing Rules DTR 7.1.5 R and 7.2.7 R which are both satisfied by Code compliance.

17 Code Provision D.2.3

18 FRC, Internal Control: Revised guidance for directors on the Combined Code (London: FRC October 2005).

19 A Belcher, “'Something distinctly not of this character': how Knightian uncertainty is relevant to corporate governance" (2008) 28(1) Legal Studies 46-67.

20 Some of the special health boards in Scotland do e.g. the Scottish Ambulance Service; some do not e.g. NES. 
director. Clearly, at board level, if not subcommittee level, the two strands of risk have to be brought together for overall risk to the health board to be considered. Some of the problems the NHS is encountering in relation to Turnbull's construction of all internal control being about risk management is due to the fractured governance terminology that has been adopted in the NHS where clinical, staff and corporate governance have their own definitions and silos of work, and what would be considered in the private sector to be (overall) corporate governance seems to have taken on the label "healthcare governance" or in the NHS in England "integrated governance":

Integrated Governance is a co-coordinating principle. It does not seek to replace or supersede clinical, financial or any other governance domain. Rather it highlights their vital importance and their inter-dependence and interconnectivity. ${ }^{21}$

In Scotland the publication of National Standards for Clinical Governance and Risk Management has, if anything, added to the confusion as these standards present a muddled and overlapping list of governance and management elements, ${ }^{22}$ including the aspiration of "public involvement" which has its origins in earlier political policy-making and is discussed below.

\section{NHS Scotland governance developments}

One of the Scottish National Party (SNP) Government's key policies for the NHS in Scotland is "public involvement". This policy can be traced back to two Patient Focus and Public Involvement Frameworks for 2003-05 and 2006-09 instituted under the previous administration. ${ }^{23}$ These incorporated a set of targets for all NHS boards (territorial and special) in Scotland with progress being monitored by NHS Quality Improvement Scotland (QIS). The public involvement element has not so far been applied at board level. However, in 2008 the Scottish Government announced its desire to improve public and community involvement in local NHS services and proposed to introduce direct elections to NHS Boards in order to "ensure that the voice of local people and communities is heard when major decisions are being made" and promote "effective governance across the public services". ${ }^{24}$ These proposals specifically mention governance, but also refer to strategy. Proposals were published as the Local Healthcare Bill: Consultation in January 2008. An analysis of responses to the consultation has been published and the Health Boards (Membership and Elections) (Scotland) Bill has been introduced in the Scottish Parliament. These events appear to have been timed approximately to coincide. The analysis purports to look forward to the Bill but the Bill was introduced in Parliament on 25 June 2008 and the analysis was published on the Scottish Government website on 3 July 2008. The analysis states that: "The issues raised as a result of the consultation will now be considered in the drafting of the Local Healthcare Bill." In fact, the differently named Health Boards (Membership and Elections) (Scotland) Bill had already been introduced. The analysis of responses acknowledges that there are problems with the idea of elected members on NHS boards, but manages to conclude that there is a need to proceed carefully, despite the fact that many respondents said they would favour not proceeding at all. The need for caution is followed through in the Bill's provisions for a pilot scheme:

Department of Health, Integrated Governance Handbook 2006, Gateway Reference 5947 (London: DoH 2006), p 3.

2 Clinical Governance and Risk Management - National Standards (Edinburgh/Glasgow: NHS QIS 2005).

23 Patient Focus and Public Involvement Framework 2003 (Edinburgh: NHS QIS 2003); and Patient Focus and Public Involvement Framework, 2006-09 (Edinburgh: NHS QIS 2006).

24 Scottish Government, Local Healthcare Bill: Consultation (Edinburgh: Scottish Government January 2008). 


\section{Pilot scheme}

(1) Ministers may by order (the "pilot order") appoint a day on which sections 1 to 3 are to come into force in respect of the Health Board areas specified in the order.

(2) Ministers may make one pilot order only (but this does not affect Ministers' power to modify or revoke the order).

(3) The pilot order may bring sections 1 to 3 into force with such modifications as Ministers consider appropriate.

\section{Report on pilot scheme}

(1) No later than 5 years after the earliest Health Board election to be held in a Health Board area specified in the pilot order, Ministers must publish a report containing- . . .25

The analysis also notes the limits of the consultation exercise as follows: "It should be noted that the findings contained in this report are specific to this consultation exercise and do not necessarily reflect the weight or range of views within the population as a whole."26

If factors are worth noting in the context of a consultation exercise, they are equally worth noting in the context of a local election process. The person elected will be the result of a specific process with voting on a specific day and a potentially low turnout. The views of the person elected will not necessarily reflect the weight or range of views within the population, or local community, as a whole. These factors appear to have been used in the context of the consultation process as a good reason for ignoring the many voices saying that the whole elected-members project should be shelved. NHS boards will just as easily be able to use similar arguments to set aside views of individual elected members if they claim to speak for the community. Also, many of the strategic and policy decisions that, in the private sector, would genuinely be made at board level are, in the NHS in Scotland, made by the Scottish Government Health Department (SGHD). Elected members may think that they will be "making the voice of the local community heard" on their NHS board, but may not realise the constraints placed on board decision-making by SGHD.

Some of the key contents of the Bill will now be summarised in order to point out some specific problems and some more general conceptual mismatches. The Bill provides for NHS Boards (territorial not special) in Scotland to have a number of directly elected members. The new health board structure will consist of the following types of member: (a) appointed members, (b) councillor members, and (c) elected members. The Bill also provides that the total number of councillor members and elected members of a board must amount to more than half the total number of members. One of the interesting aspects of the Bill is that the franchise is expanded to include those sixteen years and over. In relation to corporate governance, the most important aspects of the process are not specified in the Bill itself. Who is qualified to be a candidate in a health board election and the circumstances in which an individual may be disqualified from being a candidate are matters left for election regulations permitted by the Bill. The consultation process included questions about disqualification and eligibility criteria. On disqualification, the analysis of responses states that: "It was felt that the standard exclusions of those seeking election to the Scottish Parliament or local authority should be used. This would mean consistency of approach." 27

25 Health Boards (Membership and Elections) (Scotland) Bill 2008.

26 Ibid., p. 11, para. 11.

27 Ibid., p. 19. 
On eligibility, question 9 of the consultation asked: "What eligibility criteria should candidates meet (e.g. should they be resident in the Board area? Should there be any other qualifications?)." 28

The analysis of responses only makes reference to the first suggested question. It states:

There was strong feeling that the candidates for election to an NHS Board should be resident in that Board area. This, it was felt, would bring that necessary local experience and identity to the Board and allow communities to identify strongly with their elected representative on the NHS Board. ${ }^{29}$

The part of the question dealing with "other qualifications" is ignored, but the executive summary lists some concerns that include: "Concern that the skills that are brought to a Board by Members going through the Public Appointments process could be lost." 30

For special health boards, which have no Local Authority members, the non-executive members all go through the public appointments process, with the single exception of the employee director. The author or this article is currently a non-executive member of the board of NHS Education for Scotland, a special health board with a budget of approximately $f 400$ million per annum that has a wide education and training remit encompassing all healthcare workers. In particular, it is responsible for all postgraduate training of doctors, and programmes for dentists, pharmacists, nurses, audiologists, healthcare scientists, etc. I was appointed through the public appointments system. This included a job specification and a person specification, both including essential and desirable qualities, skills or qualifications to be found in an appointable candidate. These two lists could be described as the "qualifications" for appointment. This part of the appointment process is in line with private sector corporate governance guidance that suggests non-executive appointments should begin by identifying any skills gaps on the board as a whole. The NHS office I applied for had the audit committee "recent relevant financial experience" requirement as essential. I was appointed in June 2006, before the current SNP Government came to power. I understand anecdotally that the implementation of the public appointments system has become even more rigorous under the SNP. The interview process, organised by the office of the Commissioner for Public Appointments, results in names being sent to the minister who has the final say and makes the appointment. Recently, the minister has not dealt with this based on the paperwork alone but has called those named for a face-to-face meeting, in effect a further interview. This suggests that, in making non-executive appointments, selection of an applicant with the right skills, qualifications, and personal attributes is seen as important. This fits with the private sector view of non-executive appointments. However, the process of specifying the skills required and seeking the best match possible will be lost for all posts filled by direct election. There is no indication that the eligibility regulations will have any skills or qualifications elements. It seems that these regulations are likely to focus solely on residency. Given that the total number of councillor members and elected members of a board must amount to more than half the total number of members, the number of executive directors and appointed non-executives must amount to less than half. In order to keep within this rule, boards will either have to increase in number from their present size, or the number of appointed non-executives will have to be reduced. In general, it is thought that increasing the size of a board is likely to detract from the quality of its decision-making. It seems likely

28 Health Boards (Membership and Elections) (Scotland) Bill 2008, p. 18.

29 Ibid.

30 Ibid. 
therefore that the introduction of elected members will result in a fall in the number of appointed non-executive members, and hence the concern about a possible loss of skills.

The Health Boards (Membership and Elections) (Scotland) Bill was introduced only weeks after the launch, jointly by the Scottish Government and NHS Scotland, of a Board Effectiveness Project. In May 2008, a national engagement event was held with the aim of disseminating some preliminary research results, discussing what constitutes best practice, and developing a performance tool to evaluate board effectiveness. This project was thought to be necessary following the financial and governance failures of NHS Western Isles which culminated in the removal of power from board members, the sending in of a task force, and detailed scrutiny by the audit committee of the Scottish Parliament. Dr Kevin Woods, Director General for Health and Wellbeing, Scottish Government, appeared before the Parliamentary Audit Committee in October 2008 and will have to report to it on progress again in May 2009. I was one of the participants at the national engagement event and one of the questions raised was how this initiative would, or could, add to the existing Good Governance Standard for Public Services. ${ }^{31}$ Dr Woods' evidence to the audit committee on 8 October 2008 included the following statement:

Let me add one general point on board effectiveness. Having reflected on what we can do if a whole board is in difficulty, we have begun some work on board effectiveness and the induction of non-executive and executive directors to board positions. We are developing specific training materials that will supplement the "On Board" guidance and will be aimed specifically at audit committee members and remuneration committee members. We are developing a board effectiveness tool - as it is called in the jargon - that boards can use to appraise themselves on the extent to which they are applying the guidance in documents such as "On Board". I kicked off that work earlier this year, and we are working towards launching that programme later this calendar year. That will be an important addition to the range of things that we do to ensure the effectiveness of boards as a whole. As I commented previously, we need to remember that one difficulty in the Western Isles was that the board as a whole did not function well. ${ }^{32}$

At the time of writing, very close to the end of the calendar year, the "board effectiveness tool" has not been launched. The concern for the quality of board effectiveness appears to have been driven almost entirely by the crisis in NHS Western Isles. If the board effectiveness tool is designed to assess compliance with existing guidance, it is likely to have recognisable corporate governance themes at its heart, for instance, the roles and necessary training of non-executive, and possibly executive, board members. This initiative appears to be aimed towards improvement of board members' skills and the exercise of those skills. However, the consultation process on directly elected board members has already registered a level of concern about the possible loss of boardroom skills as a consequence of the Health Boards (Membership and Elections) (Scotland) Bill. The needs for better, and better exercised, skills that have been identified in the wake of the NHS Western Isles crisis only serve to increase those concerns.

\section{Public involvement, public participation, public interest}

It is clear from the sequence of events and policy documents set out above that the idea of public involvement in the NHS in Scotland has been driven by political ideology rather than growing out of political theories of public involvement, public participation or the public

31 Independent Commission, Good Governance Standard, n. 6 above.

32 Proceedings of the Scottish Parliamentary Audit Committee, 8 October 2008, cols 686-7. 
interest. The Scottish Government asserts that directly elected members will "ensure that the voice of local people and communities is heard when major decisions are being made" and promote "effective governance across the public services". The possible loss of governance skills identified in the previous section must raise questions about the overall impact of the elected members on the effectiveness of governance. The connections between directly elected members and accepted theorising about public participation, public involvement and the public interest are equally underdeveloped in the policy documents. The governance process implicit in the statutory provisions is a combination of electoral democracy (use of the ballot box to select some board members) and deliberative democracy (deliberation in the boardroom as a crucial mechanism for making "major decisions"). In this section, some of the theoretical difficulties associated with both voting and deliberation are highlighted. Firstly, the problems of using elections as a means of identifying the public interest have long been acknowledged:

the use of direct methods [polls, interviews] of discovering what interests the public possesses can give at best only temporary opinions on transient issues ... it is obvious that the opinions expressed by the public by means of the electoral process are practically never unanimous, nor even approach unanimity ... accepting the results of elections as expressions of the public interest would involve the position that every decision made by the electorate is the best possible decision that could have been made, a position which most democratic theorists would probably wish to avoid. ${ }^{33}$

This leaves the problem of how to articulate a public interest. Benditt put forward a collective conception of the public interest as: "An act or policy is in the public interest not because at is in the overall interest of each member of the public, but because it promotes an interest of the public, i.e. an interest of anyone." 34 This definition does not answer the question of how to discover or identify a public interest. One answer is via increased public participation. ${ }^{35}$ This is at least part of the reasoning in support of public participation in the sustainable development literature where it is believed that "effective participation in decision-making processes by local communities can help them articulate and effectively enforce their common interest" 36 In the sustainability literature, participation is also, somewhat contentiously, seen as the only approach to policy-making that can incorporate the needs of all segments of society, future generations and other species, and as leading to better social choices by increasing the evidence base for decisions. ${ }^{37}$ Democratic participation is:

... where people take part in policy making as citizens, not as experts or interest advocates. Here "participation" means the direct participation of amateurs in public policy making, allowing citizens to participate with administrators and experts on a more equal basis, creating structures for face-to-face interaction over time, and allowing citizens a share in decision making ... The call for enhanced citizen participation is closely linked with a "deliberative" conception of democracy. This conception stresses the importance of on-going dialogue

33 C W Cassinelli (1958-59) "Some reflections on the concept of the public interest" 69 Ethics 48-61, at 60.

34 T E Benditt, "The public interest" (1973) 1972-73(2) Philosopby and Public Affairs 291-311, at 311. For further discussion of the public, or general, interest see E Klijn and C Skelcher, "Democracy and governance networks: compatible or not?” (2007) 85(3) Public Administration 587-608, at 603-4.

35 Little has been written on the public interest in a corporate context but, for one example, see J R Branston, K Cowling and R Sugden, "Corporate governance and the public interest" (2006) 20(2) International Review of Applied Economics 189-212.

36 S Baker, Sustainable Development (Abingdon: Routledge 2006), citing Brundtland, p. 42.

37 Ibid. 
between citizens. This contrasts with the more traditional forms of sporadic, passive, procedural participation, such as voting ... This form of participation is not aimed at giving a voice to individual preferences or interests for their own sake. Rather, it aims at finding a voice for the common good. ${ }^{38}$

Deliberative democracy has also been contrasted with the dominant model of political scientists based on rational choice theory. That theory assumes fixed preferences or, at least, fixed ordering of preferences, whereas deliberative democracy is defined in terms of individuals participating in democratic processes amenable to changing their minds and preferences as a result of the reflection induced by deliberation. ${ }^{39}$ One definition of deliberation is "the endogenous change of preferences resulting from communication". 40 Some of the theoretical difficulties in this area include the relationship between "deliberation" and "discourse", terms that are sometimes used as alternatives; and the relationship between deliberative modes of operation and more formal democratic modes such as voting. The "discourse" debate has been summarised as follows:

To one school of thought, followers of Michel Foucault, a discourse is like a prison; it conditions the way people think. To another school of thought, influenced by Jurgen Habermas, discourse means precisely the opposite: it is pure freedom in the ability to raise and challenge arguments. The approach I take here [in a book on Deliberative Democracy] emphasizes contestation across discourses in the public sphere as a key component of democracy, so discourses are not prisons. On the other hand, discourses in the Foucauldian sense do exist, so discourse in the Habermasian sense cannot wish them away. ${ }^{41}$

The governance pressures to introduce directly elected members on NHS boards in Scotland undoubtedly come from the political imperative originating in the SNP's election manifesto. Public involvement in the NHS, via other mechanisms and below board level, had been NHS policy within the Patient Focus and Public Involvement Frameworks for 2003-05 and 2006-09. The Health Boards (Membership and Elections) (Scotland) Bill takes public participation to board level using direct elections, but, seemingly, with a view to the directly elected voice being part of the deliberative process in the boardroom. This means that other significant problems associated with deliberative democracy need to be addressed: Johnson has put these firstly, and generally, as a minimum requirement for "an account of how deliberative processes interact with non deliberative decision-making procedures like voting" 42 and, secondly, the need for a ". . .clearer understanding of how deliberative arrangements relate to . . f formal institutions". ${ }^{43}$ The difficulties involved in coupling voting with deliberative decision-making could become the most intractable in practice. The elected members are likely to have stood for election with a particular manifesto, whether of their political party or on a single issue. This in turn may lead them to believe that they are mandated to argue or vote in a particular way at board meetings. This itself has two governance consequences: the first is the tension between a perceived electoral mandate and the exercise of normal directors' duties in decision-making; the second is the difficulty of imagining directly elected members engaging in meaningful

38 Baker, Sustainable Development, n. 36 above, p. 43.

39 J S Dryzek, Deliberative Democracy and Beyond: Liberals, critics, contestations (Oxford: OUP 2000).

40 S C Stokes, "Pathologies of deliberation" in J Elster (ed.), Deliberative Democracy (Cambridge: CUP 1998), ch. 5, pp. 123-39, p. 123.

41 Dryzek, Deliberative Democracy, n. 39 above, p. vi.

42 J Johnson "Arguing for deliberation: some sceptical considerations" in J Elster (ed.), Deliberative Democracy (Cambridge: CUP 1998), ch. 7, pp 161-84, p. 175.

43 Ibid. 
deliberation (which assumes that preferences may be changed), again in the context of strong electoral promises.

Johnson also mentions the need for a ". . . clearer understanding of how deliberative arrangements relate to ... formal institutions". ${ }^{44}$ The difficulties of coupling a deliberative decision-making process at NHS board level with "formal institutions" should not be underestimated in the particular context of the NHS in Scotland. One of the strongest formal institutions in this context is the SGHD. Stokes, writing on "pathologies of deliberation", looks for "the influence of citizens' preferences on government policy". ${ }^{4}$ While the SNP rhetoric appears to be providing a mechanism for bottom-up decisionmaking by NHS boards, overall NHS policy will remain firmly in the hands of the SGHD. There is likely to be little scope for elected board members to influence government policy, even assuming the processes of election to the board and board deliberation operate well. The SGHD exercises tight control over Scotland's national health policies and over the detailed annual health board plans that implement those policies. ${ }^{46}$ Writing in the slightly different context of public "governance networks", Klijn and Skelcher conclude that:

Engaging citizens in the development of policy often brings them into conflict at the end of the process with elected bodies like parliament or municipal councils. The studies ... find that politicians initiated interactive decision making, but were reluctant to support the process or utilize the outputs in their own decision-making. ${ }^{47}$

\section{Conclusions}

The main aim of this article was to examine the governance reform pressures and processes affecting NHS boards in Scotland. The basic corporate governance "technologies" developed in the private sector have been transferred into the NHS in Scotland, including provisions arising from the writing and revision of codes of best practice, internal control constructed as risk management, the importance of non-executive skills and the exercise of skills by both executives and non-executives. The process of transfer that began shortly after the Cadbury Report in 1992 has continued into the post-Enron period. However, as noted in relation to the earliest transfer, the translation of private sector modes of organisational governance into the public sector is not without problems. The NHS has adopted governance terminology that has tended to overcomplicate the governance of an organisation by fragmenting it into staff, clinical and corporate governance. In Scotland, the publication of National Standards for Clinical Governance and Risk Management ${ }^{48}$ has added to the confusion. These "standards" include some governance items, but also substantive delivery and management issues. Performance against the standards has been assessed by NHS QIS, an arrangement that was criticised in the Crerar Review and is to be changed:

Independence is a fundamental principle of effective scrutiny and most scrutiny bodies have a degree of independence from government and from providers. One exception is health, where scrutiny by NHS QIS is internal to the health service, because NHS QIS is itself a special health board, which makes its independence less clear. ${ }^{49}$

44 Johnson, "Arguing for deliberation", n. 42 above.

45 Stokes, "Pathologies of deliberation", n. 40 above, p. 123.

46 Local Delivery Plans. The SGHD holds health boards to account for their performance against these plans.

47 Klijn and Skelcher, "Democracy and governance networks", n. 34 above, p. 597.

48 NHS QIS, National Standards, n. 22 above.

49 L D Crerar, The Report of the Independent Review of Regulation, Audit, Inspection and Complaints Handling of Public Services in Scotland (Edinburgh: Scottish Government September 2007), p. 42. 
The use of "corporate governance" within the NHS to mean only one of several governance strands is another problematic use of terminology. The private sector understanding of corporate governance as an overall umbrella covering governance of the organisation as a whole has not transferred smoothly into the NHS setting. This is unfortunate as the failure of the board "as a whole" to function well was identified as a significant factor in the crisis in NHS Western Isles. ${ }^{50}$ The Western Isles crisis, which was NHS Scotland's mini-Enron, has provided the impetus for the national board effectiveness initiative and the promise of a "board effectiveness tool". The tool is aimed at enhancing boardroom skills and assessing the use of those skills, but at the same time there are concerns that legislation introduced for directly electing health board members may result in the NHS in Scotland losing boardroom skills. The aspiration of this legislation is to "ensure that the voice of local people and communities is heard when major decisions are being made" and to promote "effective governance across the public services". An examination of some of the theoretical underpinnings and difficulties associated with the concepts of public participation, public involvement and the public interest, revealed that these aspirations are unlikely to be met. There are theoretical and practical difficulties associated with the Health Boards (Membership and Elections) (Scotland) Bill currently before the Scottish Parliament, ${ }^{51}$ however an exploration of what good corporate governance in the public interest could mean, and could look like in practice, may be an idea that is worthy of being transferred towards the private sector.

50 Proceedings of the Scottish Parliamentary Audit Committee, 8 October 2008, col. 686-7.

51 The Bill passed Stage 3 on 12 March 2009 meaning Royal Assent could be as little as one month away. 